\title{
Conserving the Culture of Phra Prang Shrines in Thailand: The State of Ceremonial Customs in Three Thai Prang
}

\author{
Phrakhru Palad Chaiwat (Nattawat Kosit) ${ }^{1}$, Songkoon Chantachon ${ }^{1} \&$ Phrakhru Vinaitorn Manop Palapan ${ }^{2}$ \\ ${ }^{1}$ The Faculty of Cultural Science, Mahasarakham University, Khamriang Sub-District, Kantarawichai District, \\ Maha Sarakham Province, Thailand \\ ${ }^{2}$ North 1, Wat Phra Chettuphon Wimon Mangkhlaram Ratchaworamahawihan, Phra Borom Maha Ratchawang \\ Sub-District, Phra Nakhon District, Bangkok, Thailand \\ Correspondence: Phrakhru Palad Chaiwat (Nattawat Kosit), Wat Arun Ratchworaram, Wangdeum Road, Wat \\ Arun Sub-District, Bangkok Yai District, Bangkok 10600, Thailand. Tel: 66-2-465-1117. E-mail: \\ pchaiwat136@gmail.com
}

Received: June 9, 2014 Accepted: June 29, 2014 Online Published: June 30, 2014

doi:10.5539/ach.v6n2p33 URL: http://dx.doi.org/10.5539/ach.v6n2p33

\begin{abstract}
Ceremonial customs at Thai prang temples are important reflections of national belief and heritage that must be conserved for future generations. This qualitative research was conducted from May 2011 to May 2012 using the research tools of survey, observation, interview, focus group discussion and workshop. Aimed at assessing the current conditions and problems with preservation of ceremonies in three Thai prang temples, this investigation highlights domestic and foreign tourism as major threats to heritage maintenance. The emphasis on maximisation of tourism revenue, prioritising the tourist experience and central government control has weakened local community influence and reduced the number of 'living' prang-related ceremonies. Of those ceremonies that do exist, few directly concern the prang, which instead provide a dramatic and scenic backdrop for tourists to admire. If prang ceremonial customs are to continue, tourism must take a back-seat to cultural inheritance.
\end{abstract}

Keywords: Buddhism, ceremonies, conservation, culture, customs, prang, Thailand

\section{Introduction}

Belief is invisible unless it is reflected in culture and customs. An overwhelming majority of the Thai population is Buddhist and this is revealed in the presence of Buddhist temples across the country and their associated religious and cultural ceremonies (Central Intelligence Agency, 2013; Dhamma Thai, 2004). Thai Buddhism is mainly of the Theravada school but has been influenced by strains of animism and Brahmanism present in traditional Thai lifestyle (Gombrich, 1988). As a result, there are two types of Buddhist citizens in Bangkok: orthodox Theravada Buddhists and people whose traditional knowledge has led them to believe a mixture of Buddhism and Brahmanism (Sanyawiwat, 2000). Traces of Brahmanism are more visible in the rural parts of Thailand, where people place their faith in nature, spirits and ancestors (Deesuancoke, 1984; Priyatisarnkarn, 2008; Romitanon, 1984).

Prang are architectural representations of Thai Buddhist faith. They are tall carved spires that are the main feature of Angkorian-style temples (Jantawit, 1990). Even though prang were first constructed by the Khmer civilization as centres of belief and worship over eight hundred years ago between 1177 and 1230, they have been adopted by Buddhists as places of worship (Ringis, 1990; Jiratasanakoon, 2002). Part of that worship includes organization of ceremonies and customs at the prang. Traditionally, Thai ceremonies relate to the human life-cycle and include birth, ordination, marriage and death (Kislenko, 2004). Additionally, ceremonies call for prosperity, express celebration and worship the spirits (Pongsapit, 2006).

The research team has noticed that visiting tourists and Thai locals alike are ignorant of the spiritual foundations of ceremonial customs at Thai prang temples. Indeed, it seems as though there is little or no appreciation of the cultural and religious value of these traditions. Consequently, this paper investigates the current conditions and problems with ceremonial customs at Thai prang to provide a clearer picture of cultural conservation in Thai prang temples. 


\section{Literature Review}

The Fine Arts Department of the Thai Ministry of Culture (2005) identifies five advantages of ancient ruins, monuments and archaeological sites:

- They can be used as places of artistic and historical learning;

- They can be used as tourist attractions;

- They can provide employment opportunities for the local community members;

- They can help provide work for specialists in archaeology, culture and history;

- They can reveal the development and evolution of the nation.

These advantages are not always appreciated by the local communities (Sittireut, 2002). Although there are multiple benefits that heritage sites can offer (Galla, 2012), it is the responsibility of the local community to treasure and maintain ancient ruins, monuments and archaeological sites to maximize their potential (Sandy, 1979).

The reason for the success of cultural tourism in some areas of the industry, notably ethno-tourism, is the integration of cultural conservation as part of the experience (Chaitorn, 2009; Prasert, 2008). Of the utmost importance in the integration process is the participation of the local community, without which the promotion of customs and traditions becomes inconsistent and difficult to maintain (Krittalaksana, 2008; Srisuwan, 2010). When community participation is coordinated and sustained, as in the restoration of forest temples in the Northeast of Thailand, conservation is successful (Amatayakoon, 2006; Hongsurapan, 2008; Jaemulitarat, 1999). Indeed, for the conservation of culture, customs and traditions to keep up with national development, community participation is essential (Potingam, 2004). Participation must be focused on creating culture-intensive activities that reflect local life (Chinsiri, 2004). Successful and directed community participation must fall under the leadership of local government organizations (Hantong, 2000; Kreungkrai, 2002; Peleggi, 1996). The success of tourism at temples in Thailand is largely down to the application of cultural tourism management strategies (Tammarat et al., 2006). Of particular interest to visiting tourists is the Buddhist art that can be found in the form of murals, paintings and sculptures (Phramaha Wichan Liewseng, 2001). The history of the temple and its architecture is an additional draw (Boonyaem, 2001). Despite this, Alisara Menakanit (1999) found tourism in Wat Pho to dilute the religiosity of the temple with social concerns.

Frank Matero (2008) argues that the economic benefits of tourism cause management committees to neglect heritage sites. As evidence of this, Premjit Promsarametee (2010) found the potential for cultural tourism in Bangkok to be at a high level but hindered by the state of disrepair at a number of ancient attractions. This is despite provisions in the local curriculums to educate young people in the importance of conserving local heritage (Saleeprasert, 2002). Again, the primary reason for the poor levels of maintenance is the lack of dedicated community participation (Laomee, 2009).

Local temples in Thailand continue to have a large role in everyday community life (Nakwatchara, 1982; Phrakhru Sutwisuttikun, 2009; Tierntong, 2006). Indeed, this is a pattern reflected across Asia, from India to Myanmar (Johnson, 2000; Philp \& Mercer, 1999). The stimuli for temple activities that develop the community religious consciousness and permit continued inheritance of religious ceremonies are the monks (Channarong, 2004) but they often fail to meet community expectations (Boonyomalik et al, 2005; Prommapan \& Wongsuntorn, 1996; Wiriyapinit, 2005). Sontaya Ponsri (2004) identified community consciousness and community spirituality as two of five factors in strengthening communities. However, the greatest threat to community strength and retention of traditional customs is the influence of more dominant external cultures, especially from the West (Adsakul, Wipornmaha, \& Thambuan, 1999; Suntornsarntoon, 2009).

\section{Methodology}

This qualitative research examines the state of ceremonies and customs in three Thai prang to identify problems with the conservation of traditional culture. Data was collected from documents and field research using the tools of survey, observation, interview, focus group discussion and workshop between May 2011 and May 2012. The researchers purposively selected Central Thailand as the research area, specifically: Phra Prang Sam Yod in Lopburi, Phra Prang Luang in Nonthaburi and Phra Prang Wat Arun Ratchworaram in Bangkok. The criteria for selection of these three locations were:

- They were temples central to community religious and cultural beliefs.

- Temple ceremonies held at the locations were widely accepted nationwide. 
- Local lifestyle and social conditions could be used as data to synthesize beliefs, ceremonies and customs.

The research population was chosen by purposive sampling and totalled sixty individuals from the three locations. The sample was divided into three groups. The first group (key informants) was composed of fifteen management staff at the three prang and 15 academics. The second group (casual informants) was composed of fifteen people involved with cultural and ceremonial activities at the temples. The final group was composed of local people and visitors to the three temples.

A survey was used to gather information regarding the research area and personal data of the respondents to ensure that they had been correctly classified into the three aforementioned groups. Non-participant observation was employed to record local lifestyle in communities around the three prang, activities held by the prang to promote beliefs and religious and cultural ceremonial customs. A set of structured interviews were conducted with key informants to ascertain the level of inheritance of ceremonial customs in Thai prang. The interview was in four sections. Section A asked for personal details of the respondent. Section B asked for general background information about the prang and the ceremonies and customs associated with them. Section $\mathrm{C}$ asked respondents for their opinions on the current conditions and problems with ceremonial customs in Thai prang. Section D asked respondents for their views on the inheritance and conservation of ceremonial customs. A set of focus group discussions was then held with respondents on the topic of ceremonial customs in Thai prang and key points were recorded to complete the data set. Finally, a workshop was organized to present the results of surveys, observation, interviews and discussions and to generate a set of suggestions for further development of ceremonial customs in Thai prang.

The researchers categorized their findings into four groups: 1) the history of Thai prang; 2) current state of ceremonial customs in Thai prang; 3) opinions of locals and tourists regarding activities held at Thai prang; 4) other data related to the beliefs, customs and ceremonies at Thai prang. Validation of data was carried out by data, investigator, theoretical and methodological triangulation (Denzin, 1970). Data was analysed using a content analysis method with the aim of identifying problems with the conservation of traditional culture (Krippendorff, 2004; Neuendorf, 2002). The results are here presented as a descriptive analysis.

\section{Results}

\subsection{Phra Prang Sam Yod, Lopburi}

The adoption of Phra Prang Sam Yod (Figure 1) by the Buddhist faith is visible in the Buddhist idolatry around the structures and the wooden ceilings adorned with red stars at the front. During the reign of Somdet Phra Narai Maharat (1656-1688), a wiharn (temple hall) was constructed to the East. This hall was built in the early Ayutthaya-period style and houses a large seated meditating Buddha statue as well as many smaller idols. Nowadays, the temple surroundings have been built up and many people are attracted by the excitement of feeding the resident monkeys. The architecture of Phra Prang Sam Yod has been included on the Thai 500 baht note and the whole area is still used by educational institutions as a field study trip for students (Wattanasuntorn, 2012, Interview). The prang is conserved and maintained by the Fine Arts Department of the Thai Ministry of Culture. The role of the Fine Arts Department is to protect, conserve and restore the art, culture, customs and ceremonies. An additional task of the department is to oversee the transmission and inheritance of art culture through adaptation and management of the site as a tourist attraction and education centre (Wongpaiboon, 2012, Interview). As a result of ministry involvement, the prang is a 'symbolic representation of the beliefs and faith inherited from the past and an indication of the advancements of previous civilizations' (Fonramdee, 2012, Interview). 


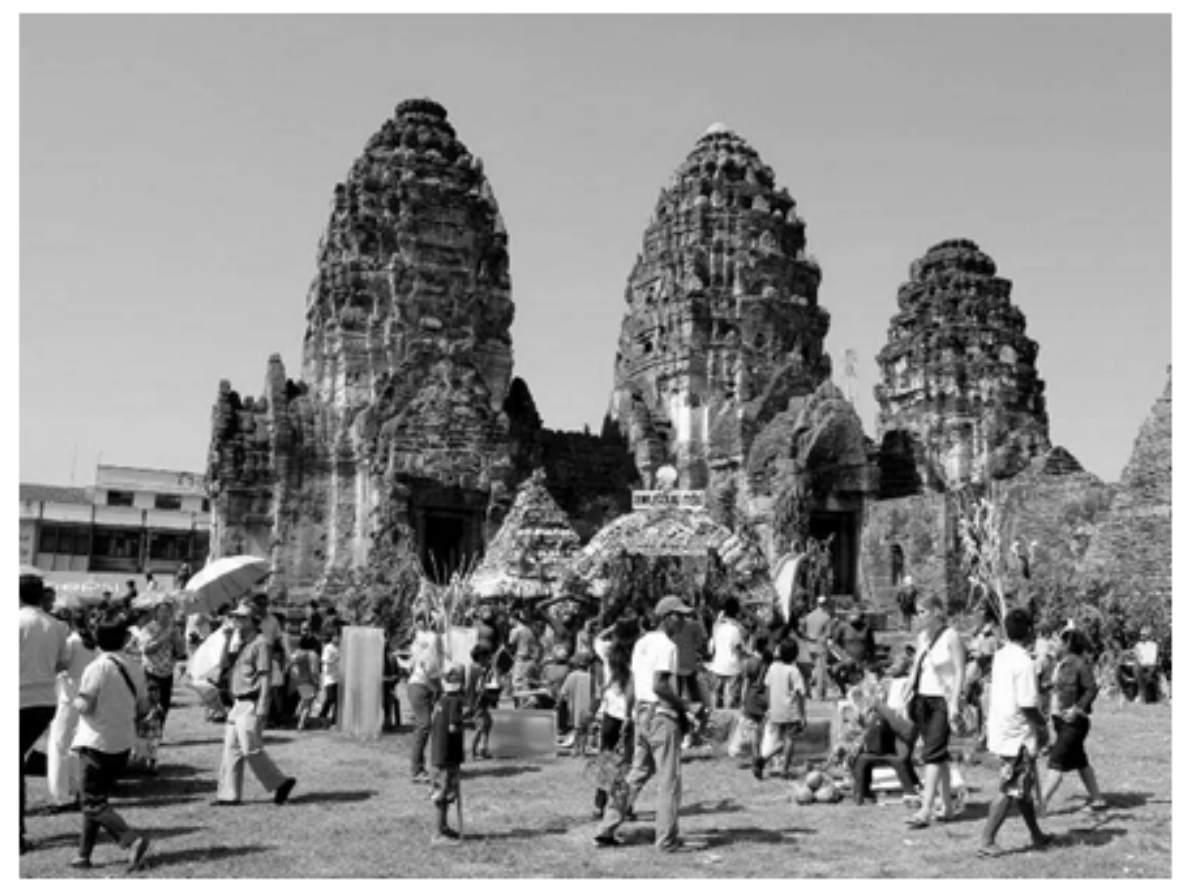

Figure 1. Phra Prang Sam Yod, Lopburi

Visitors to the prang can be categorized into three groups. The first group is tourists, many of whom are foreign. The second group is students and teachers, who come to study Phra Prang Sam Yod, King Narai Palace, Phra Prang Wad Mahatat and Prang Kaek. The third group come to make offerings at San Phra Kan (a shrine to the King of Hell) and use the opportunity to visit Phra Prang Sam Yod and feed the monkeys. Lopburi province benefits from the trade generated by these groups of people (Wongpaiboon, 2012, Interview).

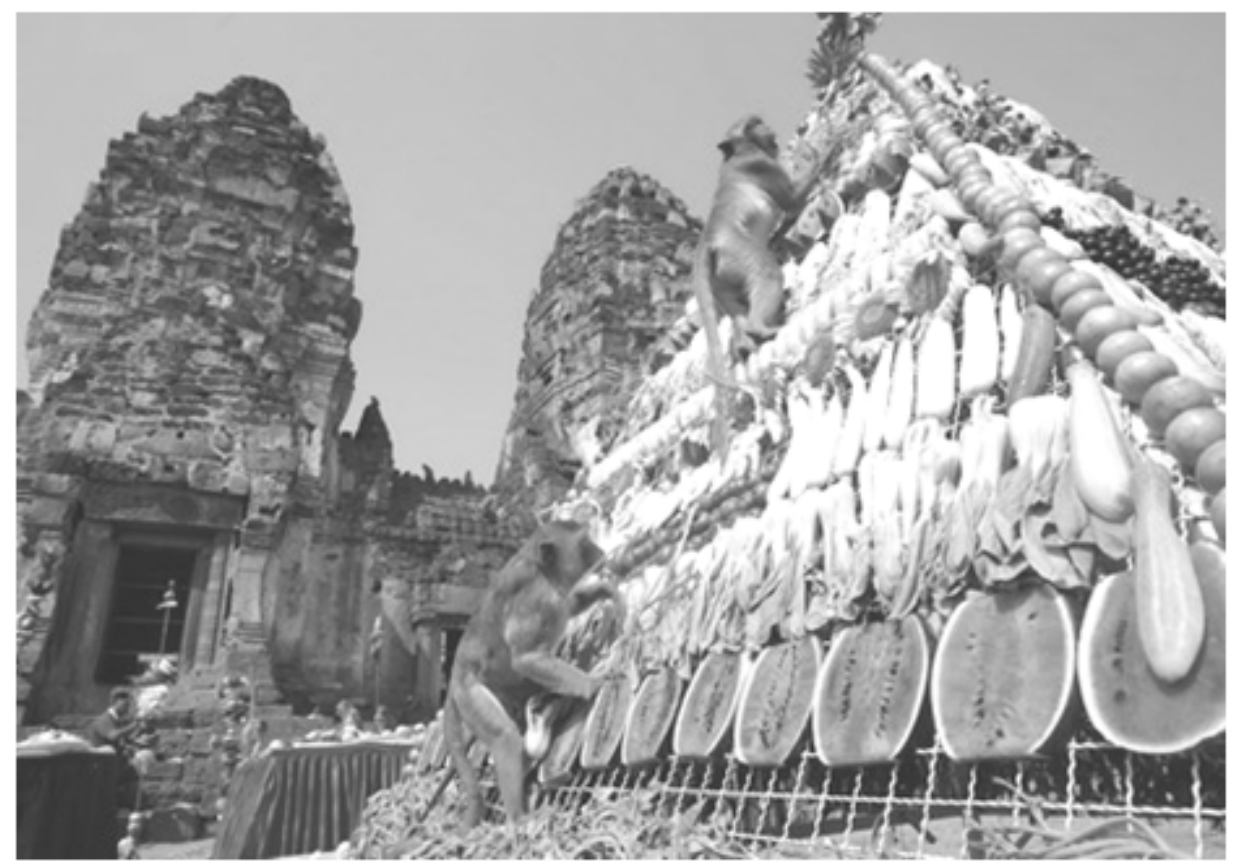

Figure 2. The monkey buffet festival at Phra Prang Sam Yod, Lopburi 
The traces of original belief still visible in the ceremonies at Phra Prang Sam Yod are those that have been adapted to suit modern society and maximize the potential benefit of tourism. One such example is the annual monkey buffet festival (Figure 2). The first monkey buffet festival was held in 1989 and has become a fixture in the provincial calendar. At the time of this investigation, the festival was in its fourteenth year. Many of the 3,000 monkeys living in and around Phra Prang Sam Yod are underfed, so the monkey buffet festival is organized once a year around the shrine for Jao Paw Phra Kan, the King of Hell (Figure 3). Locals believe that the monkeys are the holy disciples of Jao Paw Phra Kan and the festival gives people the opportunity to make merit, while also increasing tourism in the area. The festival has particular appeal for foreign tourists because of its rarity and eccentricity. 'The monkey buffet festival is organised on the last Sunday of November around the San Phra Kan and Phra Prang Sam Yod. There are many troops of monkeys, which are the main point of interest for tourists. Tourists come to pay respects to Jao Paw Phra Kan, giving food and fruit to the monkeys, which has caused the domestication of the animals and made them used to the presence of humans. There are many activities held during the festival.' (Fonramdee, 2012, Interview).

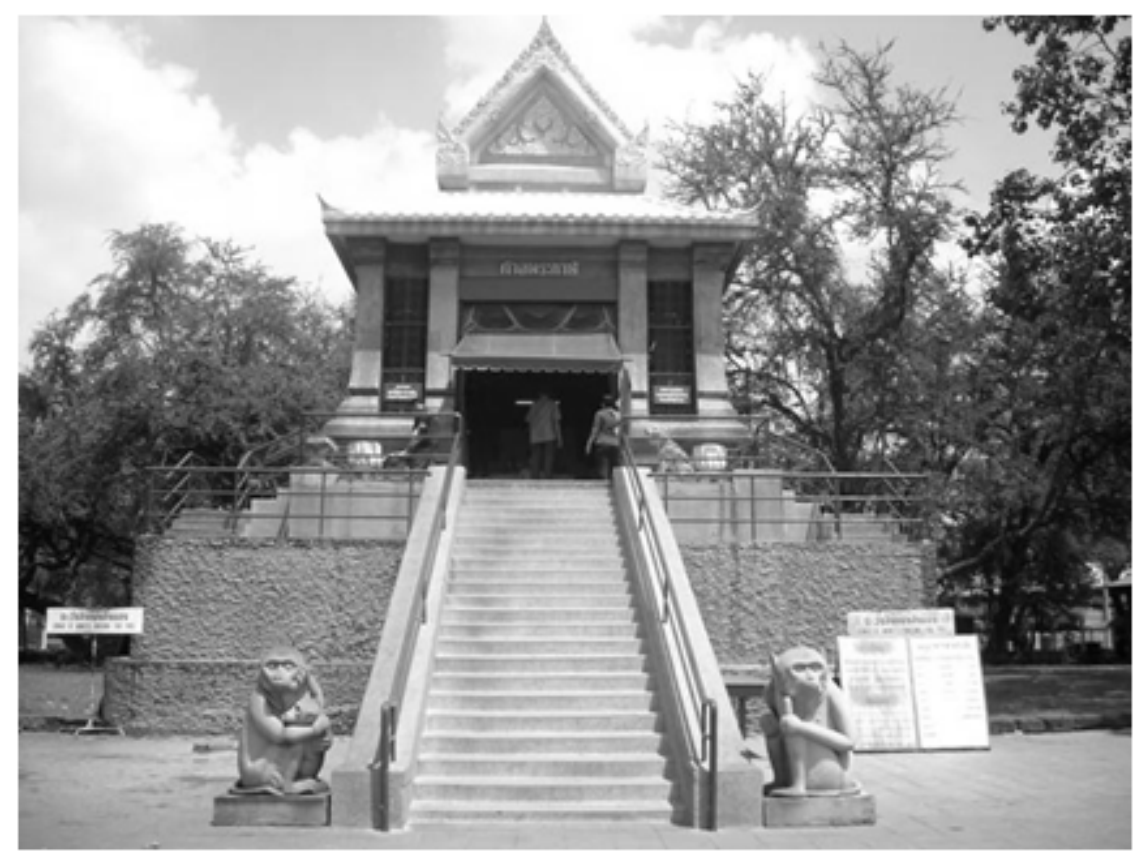

Figure 3. The shrine to Jao Paw Pra Kan, the King of Hell

The Monkey Buffet Festival has two principal aims: 1) to promote tourism and 2) to strengthen the belief that the monkeys are disciples of Jao Paw Phra Kan. Jao Paw Phra Kan is considered as much a protector of Lopburi as the city spirits and it is believed that he provides people with the ability to punish and is the spirit of death. He is thus revered by many people in Lopburi, who believe that by worshipping him they generate auspiciousness and that their enemies are deterred from persecuting them (Jeebkaew, 2012, Interview).

Aside from the Monkey Buffet Festival, there are no other ceremonies directly involving Phra Prang Sam Yod. Even though various organizations hold activities with Phra Prang Sam Yod at the symbolic centre, the temple is used for historical purposes only and there are no 'living' ceremonies or traces of worship for future generations to conserve.

\subsection{Phra Prang Luang, Nonthaburi}

The current conditions of Phra Prang Luang in Nonthaburi do not benefit belief and reverence in the Buddhist site because the majority of visitors come for tourism to admire the architecture rather than worship (Phra Somchai Patipalo, 2011, interview). In the past it was 'believed that the prang was a representation of the Lord or the heart of the universe but now people see this as a story and the sincerity of worship practice lies in culture rather than faith. There are the customs of wrapping the prang in cloth during the Kao Pansa festival, splashing water on the prang on Songkran Day and parading around the prang after Awk Pansa' (Jamlong Matieng, 2011, Interview). 
The biggest problems are that the ceremonies and customs of the ancestors have stopped being inherited and that many places of artistic value are not continuously conserved. This causes the artistic locations to become rundown and in states of disrepair (Figure 4). This is despite government initiative to mobilize the people in restoring and conserving their cultural heritage.

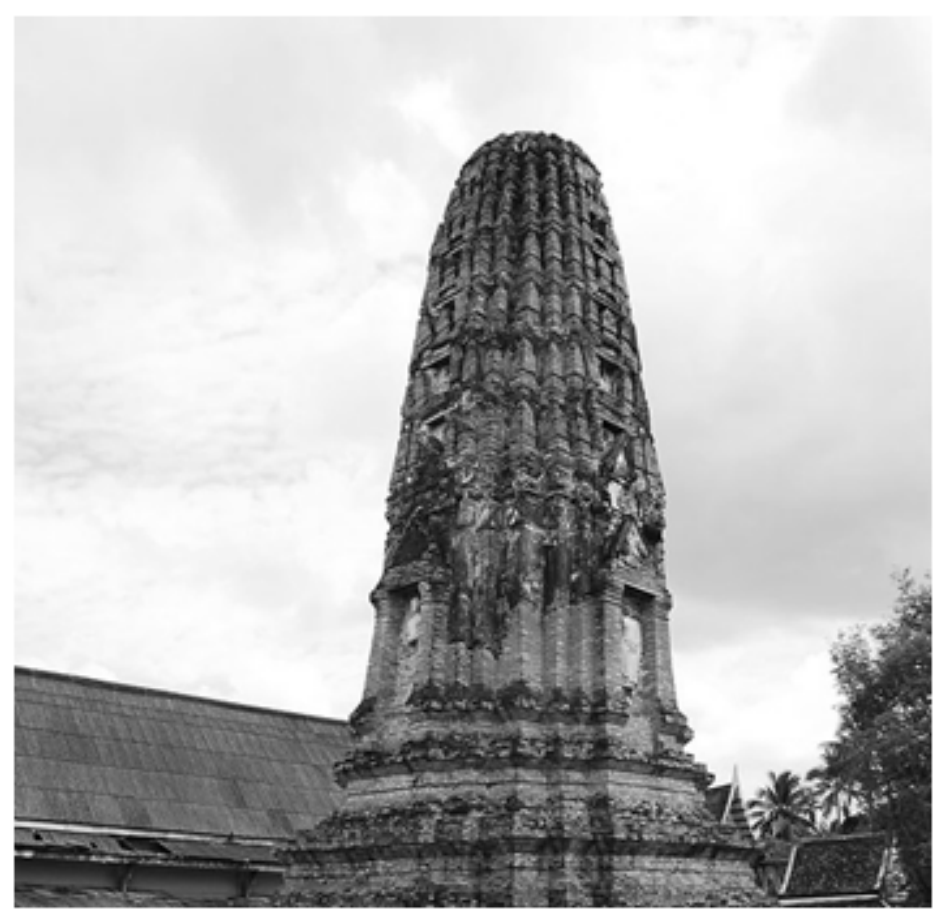

Figure 4. Disrepair of the ruean tat of Pra Prang Luang, Nonthaburi

People no longer use the principles of Buddhism as the foundation for their visits (Phra Somchai Patipalo, 2011, interview). Similarly to Phra Prang Sam Yod, Phra Prang Luang was constructed as a representation of the Lord Buddha to contain relics and remains of the revered dead. The ultimate purpose of the prang was to provide descendents with a place of worship. It was believed that bones of the deceased should be kept in the stupa as points of worship and reverence. However nowadays, there is no culture of belief about the results of worshipping the prang, people do not know the original purpose of the prang and are ignorant of the customs and ceremonies surrounding the prang (Sawatdee Puwanitlawan, 2011, interview).

\subsection{Phra Prang Wat Arun Ratchawararam, Bangkok}

There are many ceremonies focused on the beliefs of the people, such as séance, exorcism and various vow-fulfilling procedures. Wat Arun Ratchawararam is a centre of cultural learning and general education that has aided the development and evolution of national art and culture. Particular ceremonies once held at the prang were an overnight communal prayer ceremony to mark the New Year, sprinkling of water on the prang during the Songkran Festival, wrapping the structure in cloth for Khao Pansa and parading soft drinks around the prang after Awk Pansa. These ceremonies are no longer observed (Sukniranod Daorueang, 2012, interview).

It is difficult to organise activities to promote the culture and customs of the temple because the temple is a national treasure. Phra Prang Wat Arun Ratchawararam is a special level temple commissioned by the Great King. As such, permission must be asked before any activity is arranged and that activity must not go against modern social conditions. 'Society does not recognize some activities. The prang is a valuable piece of architecture that is popular with foreign tourists. The organization of temple activities inconveniences visiting tourists (Sukniranod Daorueang, 2012, interview).

It is not made clear how the culture and customs made visible at Phra Prang Wat Arun Ratchawararam are related. This is necessary because of the disappearance of original culture from everyday life in Thailand, as caused by the saturation of Thai culture with foreign influence. Rather than being a sacred place for the promulgation of religious belief, Phra Prang Wat Arun Ratchawararam has primarily become a tourist attraction. The original ceremonies of Phra Prang Wat Arun Ratchawararam have disappeared due to a lack of systematic 
inheritance. Nowadays, the temple only holds activities on important annual religious and cultural days, such as Songkran, Loi Krathong, Magha Puja, Asalha Puja and Visak, as well as at the special request of government institutions.

In the past, Thai people respected and worshipped those things necessary for human survival. As a result, related spirits were given higher importance. One such example is the water goddess Phra Mae Kong Kha, who is respected every full moon evening of the 12th month in the traditional Thai lunar calendar. This is known as the Loi Krathong Festival and Phra Prang Wat Arun Ratchawararam is just one of many places that organises festivities (Figure 5). Actually, the festival is nothing to do with Phra Prang Wat Arun Ratchawararam but its organization encourages people to respect and maintain the site.

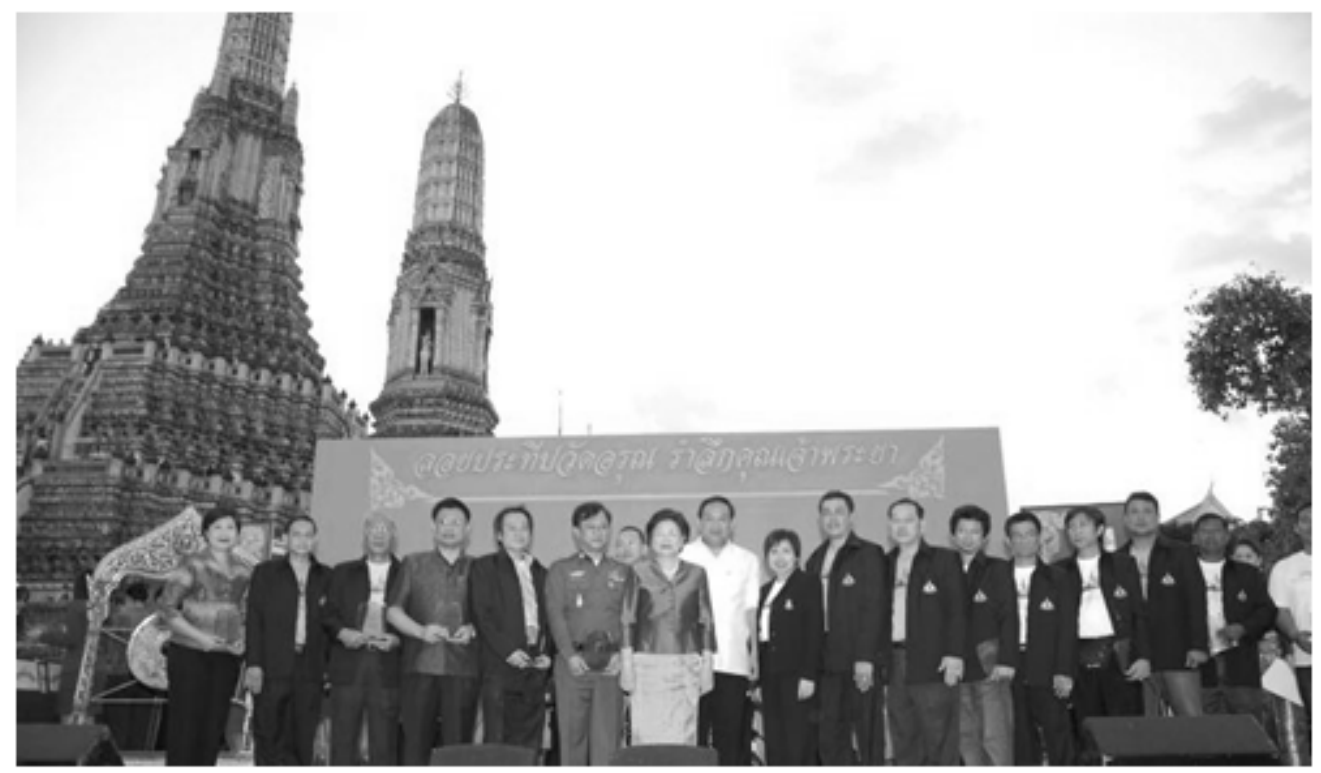

Figure 5. The Loi Krathong Festival at Phra Prang Wat Arun Ratchawararam

\section{Discussion}

The conservation and inheritance of prang falls under the authority of the department of fine arts in the Thai Ministry of Culture. While it is the main responsibility of the ministry to maintain, restore and preserve Thai architectural and cultural heritage, they must also consider the importance of the tourism industry to the Thai economy. For this reason, the preservation of ceremonial customs in the three Thai prang studied here has suffered. While tourists flock to see events such as the Monkey Buffet Festival in Lopburi, more mundane religious and cultural ceremonies for the local community are considered as disruptive to the tourist experience. In each of the three locations, the problems are similar: ceremonial customs are unrelated to the prang, which only serve as architectural and symbolic backdrops. Even Phra Prang Wat Arun Ratchawararam, with all its important religious significance, hosts only the major national ceremonies. These findings correspond to those of Boonsri Prommapan and Kittipong Wongsuntorn (1996), which identify a crisis of confidence in Buddhism. According to Prommapan and Wongsuntorn, the majority of Thai people do not know the origin of their faith, neglecting once common traditions, causing them to decline and disappear.

Prang were constructed and modified on the foundations of Brahman and Buddhist beliefs and styled according to ceremony and culture, yet, with the death of organized Brahmanism and an increasingly Westernized Thai society, these traditional beliefs are at least becoming diluted, if not disappearing (Phrakhru Palad Chaiwat, 2009). The research findings in this investigation identify a diminishing social significance of traditional Buddhist ceremonies (Religion and Ethics Newsweekly, 2013). Although McDaniel (2011) denies Buddhism is a religion in crisis, it is difficult to deny the threat of economic prioritizing and tourist influence to ceremonial customs in Phra Prang Sam Yod, Phra Prang Luang and Phra Prang Wat Arun Ratchawararam.

In their study of the commodification of Buddhism in contemporary Burma, Philp and Mercer (1999) found that Buddhism can work alongside and in relation to tourism successfully. In their research, Philp and Mercer concluded that government emphasis on religious symbolism strengthened tourism and the economy in the 
country, which in turn strengthened community belief. The approach in Myanmar, and indeed successfully managed temples in Thailand, is somewhat different to the approaches found in Phra Prang Sam Yod, Phra Prang Luang and Phra Prang Wat Arun Ratchawararam (Phrakhru Sutwisuttikun, 2009). Notably, the three temples investigated in this study are governed by the ministry of culture, rather than community groups. As Philp and Mercer (1999), Phrakhru Sutwisuttikun (2009), Hantong (2000), Kreungkrai (2002) and Peleggi (1996) have all noted, the success of ceremonial custom conservation and inheritance in these three prang will be determined by the levels of local input into their management.

In light of these findings, the researchers can make the following practical suggestions to safeguard ceremonial customs in Thai prang: Management of the three prang should employ conservation and ecotourism models of management to improve the quality of tourism and reduce its negative effects (Pedersen, 2002). Local community and religious leaders should study this research and use it as a foundation for development of religious sites in the community. The results of this research should be used by the government to challenge or enhance their concepts of heritage site management and cultural conservation. Further study should concern ruined prang in Thailand, the reasons for their decline, their potential for tourism and ways to prevent repetition of their fate in functional Thai prang.

\section{Conclusion}

Thai prang are architectural representations of Buddhist faith and their ceremonies are ways to maintain that faith. This examination of three symbolic prang in Lopburi, Nonthaburi and Bangkok found that the greatest threats to the conservation of ceremonial customs are commercial tourism and local ignorance. For successful conservation and inheritance of priceless prang traditions, community participation and government support must focus on strengthening temple culture over the financial benefits of tourism.

\section{References}

Adsakul, S., Wipornmaha, S., \& Thambuan, N. (1999). Preservation of the cultural identity of Mon people: A case study of the Mon people in Ban Muang, Ban Muang Sub-district, Ban Pong District, Ratchaburi Province [in Thai]. Research report. Bangkok: Chulalongkorn University.

Amatayakoon, N. (2006). The social factors, influences and community participation in cultural tourism, Koh Kred Community, Nonthaburi [in Thai]. Unpublished doctoral thesis. Rajanagarindra Rajabhat University, Thailand.

Ariyatamomo, P. T. (Yossakun), et al. (2006). Conservational tourism management strategies at Wat Phra Mahathat Woramahawihan, Nakhon Si Thammarat Province. Research Report. Bangkok: Yanasangvorn Research Institute, Mahamakut Buddhist University.

Boonyaem, O. (2001). Study of the opinions regarding tourism in Phra Sri Sanpet Temple [in Thai]. Ayutthaya: Phra Nakhon Sri Ayutthaya Rajabhat University.

Boonyomalik, T., et al. (2005). Temples of Dusit District: Roles and expectations [in Thai]. Unpublished doctoral thesis, Srinakharinwirot University, Thailand.

Central Intelligence Agency. (2013). Thailand. The World Factbook 2013-14. Washington, DC: Central Intelligence Agency. Retrieved from https://www.cia.gov/library/publications/the-world-factbook/geos /th.html

Chaitorn, S. (2009). Development of a cultural tourism model for home-stays among the Lao-Viang and Lao-Song indigenous peoples [in Thai]. Unpublished doctoral thesis. Mahasarakham University, Thailand.

Chaiwat, P. P. (Thanya Kosit), (2009). Study of Phra Prang Wat Arun Ratchaworaram as a symbolic medium for promoting Buddhist moral code in Buddhists [in Thai]. Unpublished doctoral thesis. Mahachulalongkornrajavidyalaya University, Thailand.

Channarong, W. (2004). The role of the monk in the application of the buddhist teachings in community development towards the avoidance of channels to ruin: a case study of Phrakhru Silavarabhorn (Chalerm Thitisilo) [in Thai]. Unpublished doctoral thesis. Thammasat University, Thailand.

Chinsiri, S. (2004). The Development of Dhonburi Bazaar Sanamluang 2 into a Cultural Tourist Attraction [in Thai]. Unpublished doctoral thesis. Dhonburi Rajabhat University, Bangkok.

Deesuancoke, C. (1984). Belief: Foundations of Isan civilization [in Thai]. Khon Kaen: Academic Resource Centre, Khon Kaen University. 
Dhamma Thai. (2004, December 31). Statistics of temples throughout the country [in Thai]. Retrieved from http://www.dhammathai.org/watthai/watstat.php

Galla, A. (Ed.) (2012). World heritage: Benefits beyond borders. Cambridge: Cambridge University Press. http://dx.doi.org/10.1017/CBO9781139567657

Gombrich, R. (1988). Theravāda Buddhism: A social history from ancient Benares to modern Colombo. London: Routledge. http://dx.doi.org/10.4324/9780203310878

Hantong, S. (2000). Tourism management potential in Pattalung Province [in Thai]. Bangkok: National Institute of Development Administration.

Hongsurapan, L. (2008). An appropriate model for the conservation, restoration and development of cultural forests in the forest temples of Isan by community participation [in Thai]. Unpublished doctoral thesis. Mahasarakham University, Thailand.

Jaemulitarat, S. (1999). Ecotourism: Opportunities and limitations for development. A case study of Koh Tao-Nang Yuan, Pha-ngan District, Surat Thani Province [in Thai]. Bangkok: Mahidol University.

Jantawit, N. (1990). The evolution of stupa and phra prang in Thailand before the $18^{\text {th }}$ Buddhist century during the evolution of Thai Buddhist sites [in Thai]. Bangkok: Ammarin Printing Group.

Jiratasanakoon, S. (2002). Buddhist temples and Thai architecture [in Thai]. Bangkok: Thammasat University Press.

Johnson, B. (2000). Sri Venkateswara Temple: Role of Sri Venkateswara Temple in India. Unpublished doctoral thesis. Baylor University, Texas.

Kislenko, A. (2004). Culture and customs of Thailand. Westport, CT: Greenwood.

Kreungkrai, P. (2002). The participation of local government organizations and the community in the management of ecological and cultural tourist attractions: a case study of Pong-ngam Sub-District, Mae Sai District, Chiang Rai Province. Unpublished doctoral thesis. Chiang Mai University, Thailand.

Krittalaksana, S. (2008). Study of the conservation, restoration and development method at ancient sites in the Tung Kula Rong Hai area with community participation [in Thai]. Unpublished doctoral thesis. Mahasarakham University, Thailand.

Laomee, B. (2009). Model for the conservation and restoration of pulpits with Phu-Tai community participation in the Isan Region [in Thai]. Unpublished doctoral research. Mahasarakham University.

Liewseng, P. W. (2001). Buddhist art and tourism: studying the role of temples in the conservation of Buddhist art for tourism [in Thai]. Unpublished doctoral thesis. Mahidol University, Bangkok.

Matero, F. (2008, June 18). Heritage, conservation and archaeology: An introduction. Retrieved from http://archaeological.org/news/hca/89

McDaniel, J. (2011). The lovelorn ghost and the magic monk: Practicing Buddhism in modern Thailand. New York, NY: Columbia University Press.

Menakanit, A. (1999). A royal temple in the Thai urban landscape: Wat Pho, Bangkok, Thailand. College Station, TX: Texas A \& M University.

Nakwatchara, N., et al. (1982). Temples in Bangkok: Change over two hundred years (1782-1982) [in Thai]. Bangkok: Chulalongkorn University Press.

Pedersen, A. (2002). Managing tourism at world heritage sites: A practical manual for world heritage site managers. Paris: Unesco World Heritage Centre.

Peleggi, M. (1996). National heritage and global tourism in Thailand. Annals of Tourism Research, 23(2), 340-364. http://dx.doi.org/10.1016/0160-7383(95)00071-2

Philp, J., \& Mercer, D (1999). Commodification of Buddhism in contemporary Burma. Annals of Tourism Research, 26, 21-54. http://dx.doi.org/10.1016/S0160-7383(98)00050-4

Pongsapit, A. (2006). The spread of culture [in Thai]. Bangkok: Chulalongkorn University Press.

Ponsri, S. (2004). Theories and principles of community development [in Thai]. Bangkok: Odeon Store.

Potingam, S. (2004). Support of community participation in the activities organized to promote religion, culture and customs at None Thai District, Nakhon Ratchasima Province [in Thai]. Unpublished doctoral thesis. Mahasarakham University, Thailand. 
Prasert, S. (2008). The method and format of conservation, restoration and development of customs and traditions of the Nyah Kur indigenous group for cultural tourism in Chaiyaphum Province [in Thai]. Unpublished doctoral thesis. Mahasarakham University, Thailand.

Priyatisarnkarn, P. (2008). A model for cultural harmonization of basic beliefs in Buddhism, Brahmanism and spirits to strengthen Isan society [in Thai]. Unpublished doctoral research. Mahasarakham University, Thailand.

Prommapan, B., \& Wongsuntorn, K. (1996). The crisis of confidence in Buddhism [in Thai]. Bangkok: Cultural Research and Development Sector Institute of Culture Education.

Promsarametee, P. (2010). Development of the potential of cultural tourist attractions for international tourists in and around Bangkok [in Thai]. Unpublished doctoral thesis, Mahasarakham University, Thailand.

Religion and Ethics Newsweekly. (2013, May 24). Decline of Buddhism in Thailand [Video file]. Retrieved from http://video.pbs.org/video/2365017076

Ringis, R. (1990). Thai temples and temple murals. Singapore: Oxford University Press.

Romitanon, C. (1984). Conditions of the economy, politics, society and culture of rural societies with resident participation: A case analysis of villages in the North [in Thai]. In T. Hongwiwat (Ed.), Community participation in development [in Thai]. Bangkok: Mahidol University.

Saleeprasert, C. (2002). Development of the local curriculum in conservation of ancient monuments and antiques of Uthong District for first-year secondary-level students [in Thai]. Unpublished doctoral thesis. Silpakorn University, Thailand.

Sandy, D. (1979). Tourism and heritage conservation. PATA Conference. Bangkok: Chulalongkorn University.

Sanyawiwat, S. (2000). Community development [in Thai]. Bangkok: Thai Wattana Panich.

Sittireut, C. (2002). Study of ancient settlements in the Tung Kula Rong Hai area: A case study of archaeological sites in Kasetwisai District, Roi-Et Province [in Thai]. Unpublished doctoral thesis. Silpakorn University, Thailand.

Srisuwan, W (2010). Model of cultural tourism management with participation of communities along the Tapi River [in Thai]. Unpublished doctoral research, Mahasarakham University, Thailand.

Suntornsarntoon, S. (2009). Model of cooperation between homes, temples, schools and communities in creating cultural immunity for children and young people in and around Bangkok Municipality [in Thai]. Unpublished doctoral thesis, Mahasarakham University, Thailand.

Sutwisuttikun, P. (2009). A management model suitable for Wat Sothonwararam in the development of social economy and culture of Chachoengsao Province from the ceremonial beliefs of the people related to Luang Por Phra Puttasothon [in Thai]. Unpublished doctoral research. Mahasarakham University, Thailand.

The Fine Arts Department of the Thai Ministry of Culture. (2005). Antiques in the national museum of Phra Pathommachedi [in Thai]. Nonthaburi: Pichit Printing.

Tierntong, K. (2006). Morality and life [in Thai]. Ayutthaya: Phra Nakhon Sri Ayutthaya Rajabhat University.

Wiriyapinit, A. (2005). Research report of the role of monks for development [in Thai]. Bangkok: National Research Council of Thailand.

\section{Copyrights}

Copyright for this article is retained by the author(s), with first publication rights granted to the journal.

This is an open-access article distributed under the terms and conditions of the Creative Commons Attribution license (http://creativecommons.org/licenses/by/3.0/). 